University of Nebraska - Lincoln

DigitalCommons@University of Nebraska - Lincoln

$10-1993$

\title{
Patterns of Morphological Variation of Salsuginus yutanensis (Monogenea: Ancyrocephalidae) over Space and Time
}

\author{
Michael T. Ferdig \\ University of Notre Dame, Michael.T.Ferdig.1@nd.edu \\ Mary Ann McDowell \\ University of Notre Dame, mcdowell.11@nd.edu \\ John J. Janovy Jr. \\ University of Nebraska - Lincoln, jjanovy1@unl.edu \\ Richard E. Clopton \\ Peru State College, RClopton@peru.edu
}

Follow this and additional works at: https://digitalcommons.unl.edu/bioscijanovy

Part of the Parasitology Commons

Ferdig, Michael T.; McDowell, Mary Ann; Janovy, John J. Jr.; and Clopton, Richard E., "Patterns of Morphological Variation of Salsuginus yutanensis (Monogenea: Ancyrocephalidae) over Space and Time" (1993). John Janovy Publications. 39.

https://digitalcommons.unl.edu/bioscijanovy/39

This Article is brought to you for free and open access by the Papers in the Biological Sciences at DigitalCommons@University of Nebraska - Lincoln. It has been accepted for inclusion in John Janovy Publications by an authorized administrator of DigitalCommons@University of Nebraska - Lincoln. 


\title{
PATTERNS OF MORPHOLOGICAL VARIATION OF SALSUGINUS YUTANENSIS (MONOGENEA: ANCYROCEPHALIDAE) OVER SPACE AND TIME
}

\author{
M. T. Ferdig*, M. A. McDowell*, J. Janovy, Jr., and R. E. Clopton \\ School of Biological Sciences, University of Nebraska-Lincoln, Lincoln, Nebraska 68588-0118
}

ABSTRACT: Salsuginus yutanensis occurs on the gills of the plains topminnow Fundulus sciadicus Cope. The fish of this species have been found to vary morphologically and biochemically among disjunct populations. Morphological characteristics of the sclerotized parts of $S$. yutanensis were examined from 3 localities in Nebraska, over a 2-yr collecting period. Analysis of variance was used to assess morphological variation with respect to site and date. Worms from 2 localities, Keith and Saunders counties, differed significantly for most characters considered. A third site, also in Keith County, contained worms for which measurement means tended to be intermediate between those in the other 2 sites. This site-related difference was maintained over a pattern of broad seasonal variation and suggests that the site-related differences are of evolutionary origin. If this interpretation is true, then the parasite populations likely are isolated in a manner analogous to those of the host. However, differences due to effects of temperature on worm development were not ruled out as possible explanations for the observations although consistent temperature differences between the sites are unlikely, given the nature of the habitats studied.

Fundulus sciadicus Cope, 1885 , the plains topminnow, serves as host for the gill monogenean Salsuginus yutanensis Ferdig, McDowell, and Janovy, 1991 (Ancyrocephalidae). The fish occur in disjunct populations in the Central Plains, Missouri Ozark, and southwestern Missouri regions. Within the endemic region, these fish are generally restricted to shallow backwaters of small, clear, spring-fed streams with moderate to heavy aquatic vegetation (Beckman, 1970; Cross, 1970; Pflieger, 1975). Using multiple morphological characters and isozyme frequencies of fish from 5 drainages, O'Hare (1985) was able to differentiate between populations that were relatively close together geographically, implying that the populations were genetically isolated regardless of their spatial proximity.

The present study examines morphological characteristics of a monogenean parasite, from $F$. sciadicus, in an attempt to determine whether parasite populations were similarly distinguishable. Monogeneans generally maintain a specific location on their hosts by attachment using the haptor, which is comprised of an assortment of sclerotized parts such as hamuli (anchors), hooks, and, depending on the species, suckers. Anatomy and measurements of the sclerotized parts are considered to be of major taxonomic significance

Received 29 January 1993; revised 20 May 1993; accepted 14 June 1993.

* Current address: School of Veterinary Medicine, Department of Pathobiological Sciences, University of Wisconsin-Madison, Madison, Wisconsin 53706. (cf. Murith and Beverley-Burton, 1985; Rand and Wiles, 1987), and in the case of Salsuginus species, variances of measurements, especially of hamuli and bars, are small (Janovy et al., 1989; Ferdig et al., 1991). For this reason, hard part measurements were chosen in order to address whether populations of $S$. yutanensis, from isolated populations of hosts, are morphologically distinguishable. The null hypothesis was that there is no difference in measurements and measurement ratios among worm populations over space and within populations over time.

\section{MATERIALS AND METHODS}

Fundulus sciadicus was seined from different springfed streams at 3 localities: Bull Ditch (SE 1/4, Sec. 19, T14N, R35W) and Cedar Creek (NW 1/4, Sec. 17, T14N, $\mathrm{R} 35 \mathrm{~W}), 1.9 \mathrm{~km}$ and $3.2 \mathrm{~km}$ north, respectively, of Paxton, Keith County, in western Nebraska, and Clear Creek (SW 1/4, Sec. 7, T14N, R10E), $5 \mathrm{~km}$ south and $3.3 \mathrm{~km}$ east of Yutan, Saunders County, in eastern Nebraska. The western sites are geographically close, but the linear stream distance between them is at least $17 \mathrm{~km}$, and several distinct aquatic habitat types are included in that distance. The 2 sites also are on opposite sides of the North Platte River. The western sites are thus considered disjunct.

Sampling of the Keith County sites took place on the same days, and sampling of the Yutan site was done within a week of those collections. A total of 419 fish, ranging from 38 to $63 \mathrm{~mm}$ long, was dissected and examined for parasites during 1988 and 1989. Fish sample sizes ranged from 5 to 20 (mean $n=17$ fish). The months and years of these collections are as follows: March 1988, May 1988, July 1988, September 1988, November 1988, March 1989, May 1989, and July 1989 . Gills were excised and placed in $1 \%$ chloral hydrate for up to $1 \mathrm{hr}$. Worms were removed with 
TABLE I. Demographic changes in Salsuginus yutanensis populations over time.

\begin{tabular}{|c|c|c|c|c|}
\hline Date & Site & $\begin{array}{l}\text { Number } \\
\text { of worms } \\
\text { collected }\end{array}$ & $\begin{array}{l}\text { Percent- } \\
\text { age } \\
\text { gravid }\end{array}$ & $\begin{array}{l}\text { Percent- } \\
\text { age } \\
\text { imma- } \\
\text { ture }\end{array}$ \\
\hline \multirow[t]{3}{*}{ March 1988} & Bull Ditch & 34 & 3 & 0 \\
\hline & Cedar Creek & 61 & 3 & 0 \\
\hline & Yutan & 53 & 4 & 21 \\
\hline \multirow[t]{3}{*}{ May 1988} & Bull Ditch & 147 & 6 & 3 \\
\hline & Cedar Creek & 713 & 6 & 1 \\
\hline & Yutan & 371 & 10 & 2 \\
\hline \multirow[t]{3}{*}{ July 1988} & Bull Ditch & 172 & 0 & 0 \\
\hline & Cedar Creek & 345 & 0 & 0 \\
\hline & Yutan & 289 & 0 & 0 \\
\hline \multirow[t]{3}{*}{ September 1988} & Bull Ditch & 57 & 0 & 0 \\
\hline & Cedar Creek & 50 & 0 & 0 \\
\hline & Yutan & 33 & 0 & 0 \\
\hline \multirow[t]{3}{*}{ November 1988} & Bull Ditch & 87 & 0 & 0 \\
\hline & Cedar Creek & 43 & 0 & 2 \\
\hline & Yutan & 56 & 0 & 2 \\
\hline \multirow[t]{3}{*}{ March 1989} & Bull Ditch & 71 & 53 & 13 \\
\hline & Cedar Creek & 53 & 29 & 8 \\
\hline & Yutan & 26 & 32 & 28 \\
\hline \multirow[t]{3}{*}{ May 1989} & Bull Ditch & 369 & 1 & 1 \\
\hline & Cedar Creek & 141 & 17 & 1 \\
\hline & Yutan & 94 & 2 & 0 \\
\hline \multirow[t]{3}{*}{ July 1989} & Bull Ditch & 106 & 0 & 0 \\
\hline & Cedar Creek & 202 & 0 & 0 \\
\hline & Yutan & 33 & 0 & 0 \\
\hline
\end{tabular}

insect pin probes, fixed in alcohol-formalin-acetic acid, washed in $70 \%$ ethanol, and cleared and mounted in glycerin. Three hundred sixty specimens of $S$. yutanensis were studied, with each site/collection combination, 24 in all, being represented by measurement data from approximately 15 worms. These 360 worms were from a total collection of 3,606; the demographic data in Table I are from the total collection. Worms were classified as gravid if they contained an egg, or immature if they were noticeably smaller than the average $S$. yutanensis and were comparatively clear under the light microscope. Worms were pooled in a vial, and the sample for measurement was drawn from the pool. When infrapopulations were low (Table I), the pool consisted of all the worms in the sample; when infrapopulations were high, the pool consisted of 5-10 per fish. Because of the small size of $S$. yutanensis and the inability to determine the individual fish host for pooled worms, formal randomization of worms selected for measurement was not considered necessary.

Measurements were taken according to the protocols of Murith and Beverley-Burton (1985) and Janovy et al. (1989). Total worm length, pharynx diameter, haptor dimensions, penis, and accessory piece were measured. In addition, 18 structural feature measurements and 11 ratios of these measurements on dorsal and ventral hamuli were used as evaluators of sclerotized part anatomy. The following standard hamulus measurements were taken and their notations are according to Murith and Beverley-Burton (1985): ventral $a$ (VA); dorsal $a$ (DA); ventral $b$ (VB); dorsal $b$ (DB); ventral $c$ (VC); dorsal $c$ (DC); and ventral and dorsal $d, e, f, g$, $x$, and $y$ (VD, VE, VF, VG, VX, VY, DD, DE, DF,
DG, DX, and DY, respectively). The $a$ measurements are total hamulus length to the tip of the superficial root; the $f$ measurements are bar lengths; $x$ and $y$ measurements are breadth and half-depth hamulus measurements, respectively. Ratios to represent shape and relative proportions were used according to the methods of Janovy et al. (1989) and Ferdig et al. (1991) as VB/VX, DB/DX, VY/VX, DY/DX, VD/VC, DD/DC, VA/VE, DA/DE, DC/VC, DA/VA, and DX/VX. Included in this analysis are the taxonomically significant characteristics along with a series of ratios relating within- and between-hamulus measurements.

Measurements were made at $970 \times$ for each worm using a compound microscope and ocular micrometer. Entries were recorded in micrometers. Every collection sample was described statistically for all characters and then plotted with respect to site and date. Each measurement of hard parts taken from an individual worm was made with respect to the most discernible example of a particular measurement regardless of which (left or right) hamulus was examined. Frequency distributions were plotted for potentially dimorphic characters to determine whether differences existed between right and left dorsal and ventral hamuli. The relationship between total worm length and hamulus length (DA and VA) was evaluated by use of Pearson's correlation coefficient.

Analysis of variance (ANOVA) was performed on sample data for each of the 18 sets of measurements and 11 sets of ratios, in each collecting period to determine the presence of site-related variation at any 1 time. Likewise, sample means from individual localities were evaluated over collecting periods to recognize variation in any 1 site attributable to time of collection. Planned pair-wise comparisons (Student's $t$-tests) were conducted when ANOVA identified significant $F$-values $(P<0.05)$. In these cases all sites were compared. Only consecutive collection periods were compared.

Each characteristic also was assessed by 2 -way ANOVA to determine whether error attributable to the interaction between site and date was negligible (site and date effects cannot be separated if interaction is present). Characters for which interaction was not significant and for which significant site and date variation was identified were examined by the above-mentioned appropriate planned pair-wise means comparisons.

All statistical analyses were performed using SAS. The ANOVAs were with and without Bonferroni and Scheffe's corrections to control for maximum error rate under either complete or partial null hypotheses.

\section{RESULTS}

Average sizes of the sampled fish varied, but not significantly, between sites and collection dates. Fish from Yutan were smallest most often (6 of the 8 collections), but their worms were not necessarily the smallest nor were sclerotized parts measurements always the smallest of those of the 3 sites (Tables II, III; Figs. 1, 5-8). Similarly, fish from Cedar Creek were the largest most often ( 6 of the 8 collections), but their worms were not necessarily the largest nor were sclerotized parts 

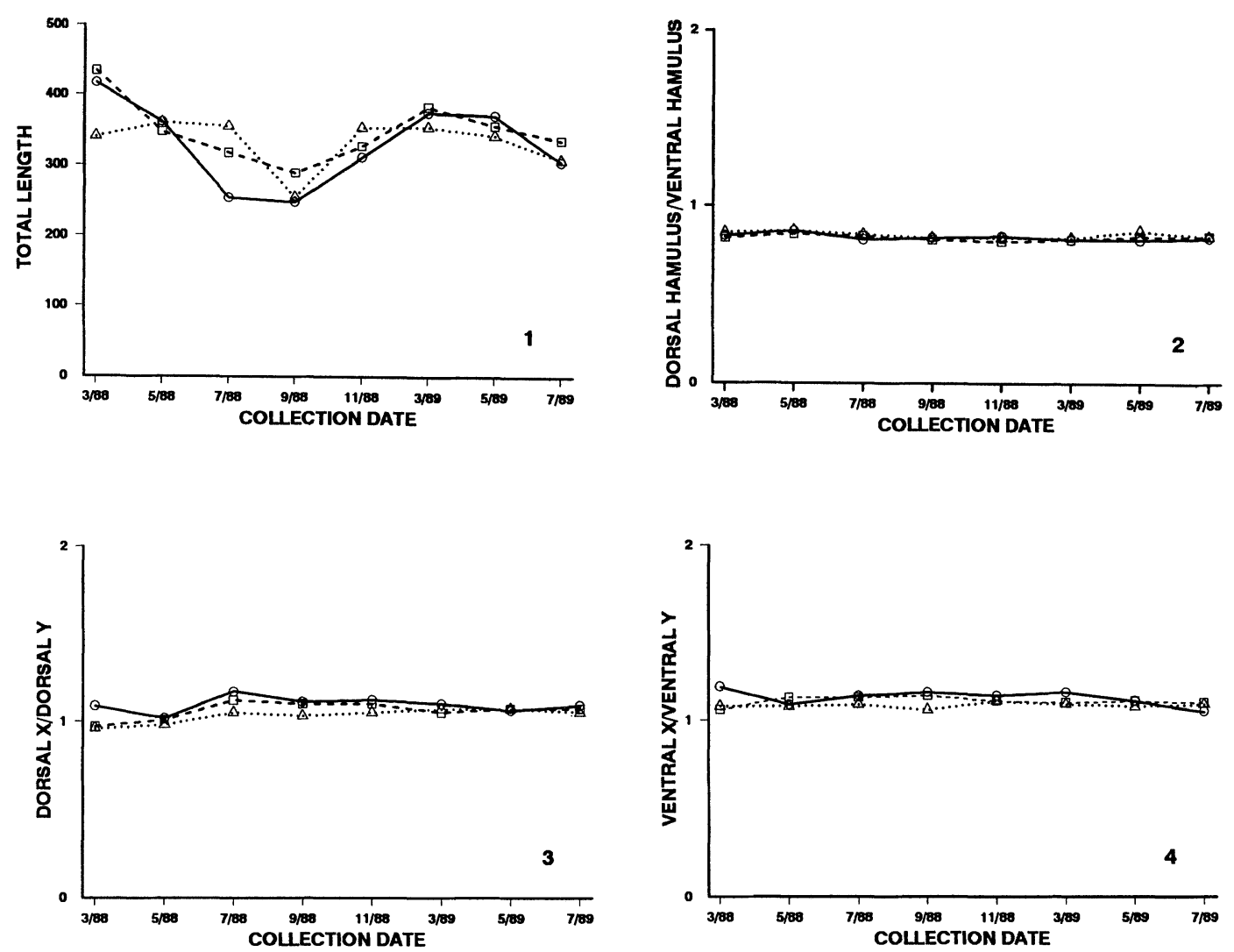

FIGUREs 1-4. Variations in Salsuginus yutanensis total worm length, ratios of hamulus lengths, and hamulus proportions over time, at 3 sites. Measurements are in micrometers. Circles, squares, and triangles indicate samples from Bull Ditch, Cedar Creek, and Yutan, respectively. 1. Variations in total worm length. 2. Relationship between dorsal and ventral hamulus lengths. 3. Ratios of measurement $x$ to measurement $y$ (Murith and BeverleyBurton, 1985) for dorsal hamuli. 4. Ratios of measurement $x$ to measurement $y$ for ventral hamuli.

measurements always the largest of those of the three sites (Tables II, III; Figs. 1, 5-8)

Frequency distributions of measurements taken from either of 2 hamuli demonstrated no dimorphism. Hamulus lengths as described by DA and VA were positively correlated with total worm length ( $r=0.16$ and 0.21 , respectively, $\mathrm{n}$ $=360$ ), but only $2.6 \%$ and $4.4 \%$ of the variation in hamulus length, respectively, therefore, could be associated with variation in total worm length.

Examples of plots of measurement and ratio means are shown in Figures 1-8. Worm length was minimum during mid-to-late summer, increased in fall, and was at its maximum in spring (Fig. 1). The ventral hamulus always was larger than the dorsal one, however, and the ratio DA/ VA was unchanged over time (Fig. 2). Regardless of their fluctuations in size, both dorsal and ventral hamuli also retained their characteristic shape as indicated by the DX/DY and VX/VY ratios (Figs. 3, 4). Dorsal and ventral hamuli both exhibited maximum sizes in spring (May of each year) and minimum sizes in midsummer to late fall (Figs. 5, 6). Dorsal and ventral bars both varied in size, in concert with the hamuli (Figs. $7,8)$.

One-way ANOVA using site as the factor revealed 22 characters that differed significantly in size between at least 2 of the 3 sites (Tables II, III). Table II gives the characters for which means were significantly different between sites but without site/date interactions excluded. That is, for some of the characters in Table II, a character from Cedar Creek worms might be larger than that from Bull Ditch worms on 1 date but smaller than that from Bull Ditch worms at another date. Nevertheless, for 11 of the 16 characters in Table II, the Bull Ditch worms were smallest. Char- 

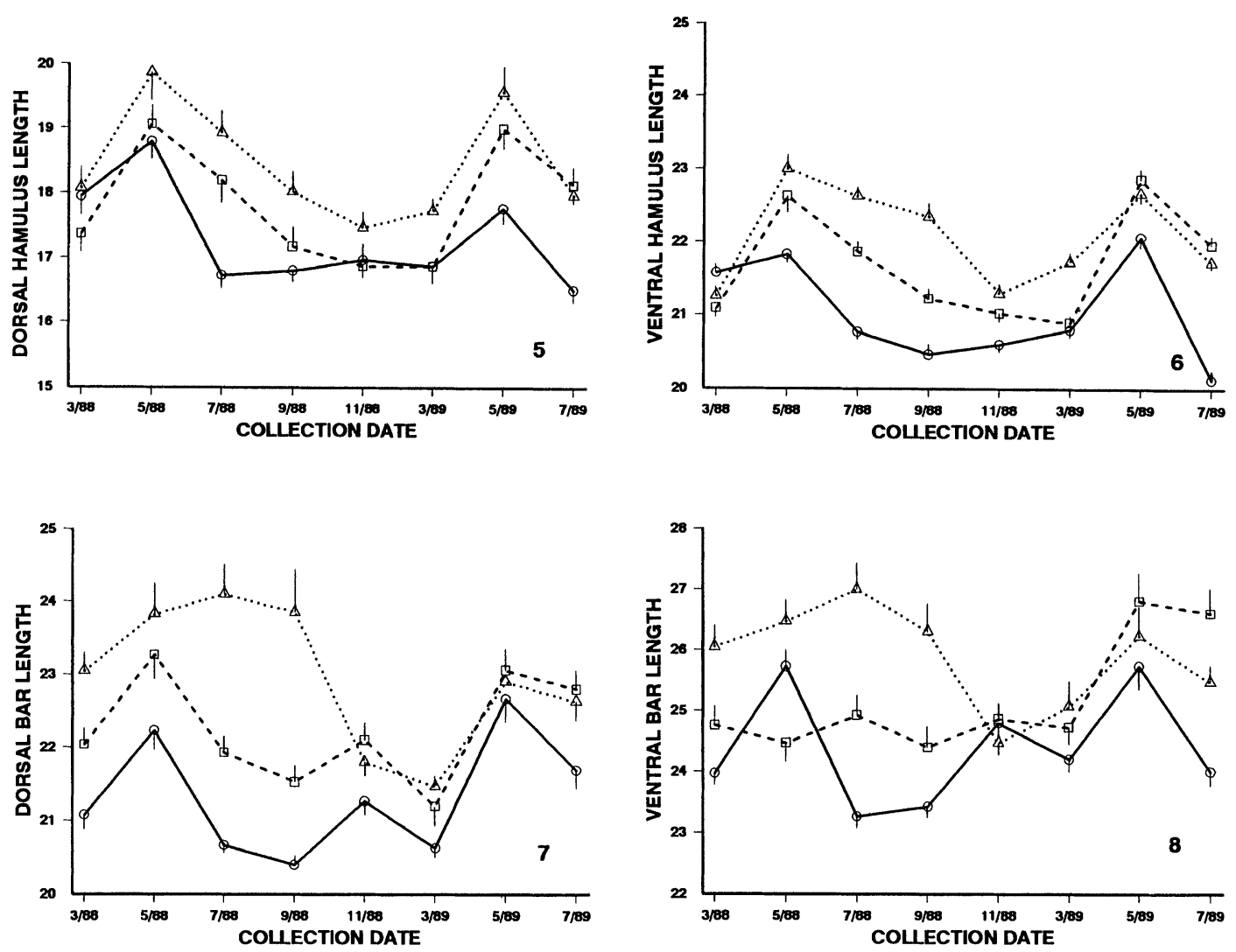

Figures 5-8. Variations in sclerotized part measurements in Salsuginus yutanensis over time at 3 sites. Vertical bars are SD; circles, squares, and triangles indicate samples from Bull Ditch, Cedar Creek, and Yutan, respectively. 5. Dorsal hamulus length. 6. Ventral hamulus length. 7. Dorsal bar length. 8. Ventral bar length.

acters mentioned in the Materials and Methods section but not listed in Table II or III did not differ significantly in size.

Two-factor ANOVA using site and collection date as factors revealed 9 traits that were free of site/date interactions (Table III). Six of these varied significantly among sites. Thus the overall variation for these data could be partitioned to demonstrate significant site-related differences independent of seasonal fluctuation in measurements. Bull Ditch and Yutan means were significantly different for all 6 of these variables (Table III). For 4 of these 6 variables Cedar Creek means were intermediate to those of the other sites, and worms from Yutan fish were largest for all characters. Date effects analyzed for the above 9 characters showed a significant main effect difference among March, May, and June collections for both 1988 and 1989. Annual fluctuations during this time accounted for most of the overall variation (Figs. 5-8).

Gravid and immature worms were most com- mon in spring (Table I), indicating a recruitment period following the spring thaw, typically from late February through April. By midsummer, the percentage of gravid and immature worms had dropped to zero.

\section{DISCUSSION}

It is generally accepted that variation is inseparable from, and broad within, biological systems, and this assertion is true for the $S$. yuta$n e n s i s / F$. sciadicus relationship. Most of the parasite's structural variation can be attributed to specific site and date effects and not to the effects of average host size. Nine characters for which there was no interaction among site and dates were used to determine that Yutan and Bull Ditch character means were significantly different for all traits shown to vary with respect to site. These 2 sites are separated by almost 500 $\mathrm{km}$. The main effect observations strengthen and reiterate those made from simple effect analysis based on all measurement data. 
TABLE II. Comparison of main effects for site as determined by planned pair-wise means comparisons of hamulus and bar measurements and measurement ratios (site/date interactions not excluded) on Salsuginus yutanensis characters.*

\begin{tabular}{lllll}
\hline Character & & Site effects & \multicolumn{1}{c}{$\begin{array}{c}P \text { of } \\
\text { equality }\end{array}$} \\
\hline DA & BD a & CC b & Y c & $0.001,0.001$ \\
DB & BD a & CC b & Y c & $0.001,0.004$ \\
DY & BD a & Y b & CC b & 0.004 \\
DF & BD a & Y b & CC c & $0.0001,0.0001$ \\
VA & BD a & Y a & CC b & $0.0001,0.0049$ \\
VB & BD a & Y b & CC b & 0.0001 \\
VE & Y a & BD b & CC b & 0.0009 \\
VX & Y a & BD a & CC b & 0.0007 \\
VY & BD a & Y b & CC b & 0.0001 \\
VF & BD a & Y b & CC b & 0.0001 \\
VG & BD a & Y b & CC b & 0.01 \\
P & CC a & BD a & Y b & 0.01 \\
DA/DB & BD a & CC a & Y b & 0.04 \\
VX/VY & Y a & CC a & BD b & 0.008 \\
VE/VA & Y a & CC b & BD b & 0.0001 \\
DC/VC & BD a & Y b & CC b & 0.005 \\
\hline
\end{tabular}

* Each character for which site effects are significant between any 2 , or among 3 of the sites, is presented. Sites are: BD, Bull Ditch; CC, Cedar Creek; Y, Yutan. If main effects varied significantly $(P<0.05)$ the significance is indicated with different letters $(a-c)$. Site means with common letters are not significantly different from one another. Site position in the table is in order of ascending mean value. Sclerotized part designations are from Murith and Beverley-Burton (1985), abbreviated as follows: DA, dorsal $a$; DB, dorsal $b$; DF, dorsal $f$; DY, dorsal $y$; VA, ventral $a$; VB, ventral $b$; VE, ventral $e$; VF, ventral $f$; VG, ventral $g$, VX, ventral $x$; VY, ventral $y$; P, $p$; DA/DB, dorsal $a /$ dorsal $b$; VX/VY, ventral $x /$ ventral $y$; VE/VA, ventral $e /$ ventral $a ; \mathrm{DC} / \mathrm{VC}$, dorsal $c /$ ventral $c$

Among the 22 characters exhibiting significant site-related differences, 10 are ratios of hamulus measurements. Although use of ratios, as characters, introduces an intangible or abstract element into morphological considerations, such use is widespread throughout the field of platyhelminth systematics. In most cases ratios are expressed as proportions or proportionate distributions of anatomical features, e.g., longitudinal extent of vitellaria or uterine coils (Schell, 1985). Furthermore, in the case of Salsuginus species, such ratios clearly established proportional differences in sclerotized parts when single-dimension measurements could not, and in addition use of ratios confirmed morphological differences revealed in drawings of hamuli that were of similar sizes but of distinctly different shapes (Murith and Beverley-Burton, 1985; Janovy et al., 1989; Ferdig et al., 1991). Finally, although some ratios varied, others, especially hamulus lengths and proportions, long used in monogenean taxonomy, were highly stable in a series of homogeneous samples. This last observation indicates that although hamulus size differences
TABLE III. Comparison of Salsuginus yutanensis characters that exhibited no site/date interaction; main effects for site as determined by planned pair-wise means comparisons.*

\begin{tabular}{lllll}
\hline Character & & Site effects & & $\begin{array}{c}P \text { of } \\
\text { equality }\end{array}$ \\
\hline DX & Y a & BD a & CC a & \\
DE & BD a & CC a & Y a & \\
VC & BD a & CC a & Y b & 0.003 \\
VB/VX & BD a & CC a & Y b & 0.0001 \\
DX/DB & BD a & CC a & Y b & 0.048 \\
DX/DY & BD a & CC b & Y c & $0.007,0.04$ \\
DE/DA & CC a & BD a & Y b & 0.007 \\
DA/VA & CC a & BD a & Y b & 0.009 \\
DX/VX & BD a & Y a & CC a & \\
\hline
\end{tabular}

* Each character for which site and date are noninteractive is presented. If main effects varied significantly (2-way ANOVA, $P<0.05$ ) the significance is indicated with different letters $(a-c)$. Site means followed by the same letters are not significantly different from one another. Site position in the table is in order of ascending mean value. Sclerotized part designations are from Murith and Beverley-Burton (1985), abbreviated as follows: $\mathrm{DE}$, dorsal $e$; DX, dorsal $x$; VC, ventral $c$; VB/VX, ventral $b /$ ventral $x$; DX/DB, dorsal $x /$ dorsal $b$; DX/DY, dorsal $x /$ dorsal $y$; DE/DA, dorsal $e /$ dorsal $a$; DA/VA, dorsal $a$ /ventral $a$; DX/VX, dorsal $x /$ ventral $x$.

between sites were maintained over most of the study period, the size relationship between dorsal and ventral hamuli did not change appreciably with the changing seasons. The debate over use of ratios as quantifiable characters likely is to continue, but in the present study, some ratios were highly stable and others varied according to collection site and date, suggesting that proportions expressed as measurement ratios may be valid taxonomic characters.

Variation in measurements of monogenean sclerotized parts has been attributed to temperature effects (e.g., Ergens and Gelnar, 1985; Mo, 1991a, 1991b, 1991c). Although these studies were done on Gyrodactylus species, they suggest some explanations for the present observations on Salsuginus yutanensis. For example, Mo (1991a, 1991b, 1991c) demonstrated, through an extensive and careful set of studies, that in $G y$ rodactylus salaris from Salmo salar, marginal hooks were significantly larger in worms developing at low water temperatures than in worms from fishes in warm water. In the case of $S . y u$ tanensis, hamuli and bars were longest in late spring, during which time (March-May) $\mathrm{Ne}$ braska surface waters thaw and the greatest percentages of gravid and immature worms appear in the population. If $S$. yutanensis and $G$. salaris sclerotized parts are affected similarly by temperature, then the sudden increase in size, from March to May collections, might be due to tem- 
perature effects on embryos developing in overwintering eggs or on a midwinter (January-February) generation of worms. It is virtually impossible to sample the research sites in midwinter in Nebraska, so the reproductive status of January and February worms is not known. The fact that no reproductive increase appeared in November, however, suggests that an annual winter reproductive cycle, if present, is stimulated by truly cold temperatures. The drop in midsummer measurements would then be due to the recruitment of worms resulting from eggs produced by adults in May, worms that developed their sclerotized parts in relatively warm waters.

In the Mo (1991a, 1991b, 1991c) studies, however, the anchor length and ventral bar width, measurements corresponding to $\mathrm{VA}, \mathrm{DB}$, and DF in the present study, did not exhibit significant regression on temperature, in G. salaris, a distinct difference from the case in $S$. yutanensis if season is related to temperature in Nebraska. And finally, the differences in reproductive mechanism, between gyrodactylids and dactylogyrids, suggest that the former may be more responsive to ambient temperature fluctuations than the latter, mainly because the required development time for $S$. yutanensis in the egg is not known. Thus immediate environmental conditions potentially affect monogenean sclerotized part anatomy, but the specific manner in which anatomy is affected cannot necessarily be generalized from published studies.

The most striking aspect of variation in the $S$. yutanensis/F. sciadicus system is the maintenance of significant site-related differences in phenotype over a broad range of variation due to seasonal factors. It is reasonable to expect that if variation is due only to proximal environmental circumstances, then the observed pattern with respect to population differences would not be so readily maintained. Depending in part on the assumed homogeneity of each of the 3 sites, it appears there is a genetic component to the observed variation. As this study was designed and conducted within the context of host variation, there is evidence that isolated $F$. sciadicus populations harbor similarly isolated $S$. yutanensis populations. Considering the direct life cycle and host habitat specificity, it is entirely possible that the observations reflect microevolutionary events. That is, the factors leading to host genetic and morphological divergence have affected the parasite gene pool as well. What this study did not examine, however, is parasite structural variation in supposedly disjunct host populations that did not themselves exhibit consistent structural or biochemical differences. Given the nature of the host species' habitat requirements, such study populations are almost impossible to find and even more difficult to verify as "disjunct."

\section{ACKNOWLEDGMENTS}

The authors thank A. Joern and L. Vescio for use of Cedar Point Biological Station facilities. This study was supported in part by the Ashton C. Cuckler Fellowship and the Jesse A. Lee Award to M.T.F. by the University of Nebraska.

\section{LITERATURE CITED}

Beckman, W. C. 1970. Guide to the fishes of Colorado. University of Colorado Museum, Boulder, $110 \mathrm{p}$.

Cross, F. B. 1970. Fishes as indicators of Pleistocene and recent environments in the Central Plains. Publication number 3, University of Kansas Press, Lawrence, p. 241-257.

Ergens, R., AND M. Gelnar. 1985. Experimental verification of the effect of temperature on the size of hard parts of opisthaptor of Gyrodactylus $\mathrm{ka}$ tharineri Malmberg, 1964 (Monogenea). Folia Parasitologica 32: 377-380.

Ferdig, M. T., M. A. McDowell, AND J. Janovy, JR. 1991. Salsuginus yutanensis n. sp. (Monogenea: Ancyrocephalidae) from Fundulus sciadicus in Clear Creek of eastern Nebraska. Journal of Parasitology 77: 58-61.

Janovy, J., JR., T. R. Ruhnke, AND T. A. WheEler. 1989. Salsuginus thalkeni n. sp. (Monogenea: Ancyrocephalidae) from Fundulus zebrinus in the South Platte River of Nebraska. Journal of Parasitology 75: 344-347.

Mo, T. A. 1991a. Seasonal variations of opisthaptoral hard parts of Gyrodactylus salaris Malmberg, 1957 (Monogenea: Gyrodactylidae) on parr of Atlantic salmon Salmo salar L. in the River Batnfjordselva, Norway. Systematic Parasitology 19: 231-240.

. 1991b. Variations of opisthaptoral hard parts of Gyrodactylus salaris Malmberg, 1957 (Monogenea: Gyrodactylidae) on rainbow trout Oncorhynchus mykiss (Walbaum, 1792) in a fish farm, with comments on the spreading of the parasite in south-eastern Norway. Systematic Parasitology 20: 1-9.

- 1991c. Variations of opisthaptoral hard parts of Gyrodactylus salaris Malmberg, 1957 (Monogenea: Gyrodactylidae) on parr of Atlantic salmon Salmo salar L. in laboratory experiments. Systematic Parasitology 20: 11-19.

Murith, D., AND M. Beverley-Burton. 1985. Salsuginus Beverley-Burton 1984 (Monogenea: Ancyrocephalidae) from Cyprinodontidae (Atheriniformes) in North America with descriptions of Salsuginus angularis (Mueller, 1934) Beverley- 
Burton, 1984 from Fundulus diaphanus and Salsuginus heterocliti $\mathrm{n}$. sp. from $F$. heteroclitus. Canadian Journal of Zoology 63: 703-714.

O'HARE, J. R. 1985. Morphological and biochemical variation of disjunct populations of the plains topminnow, Fundulus sciadicus. M.S. Thesis. University of Nebraska-Omaha, Omaha, Nebraska, $86 \mathrm{p}$.

Pflieger, W. L. 1975. The fishes of Missouri. Missouri Department of Conservation, Jefferson City, Missouri, 343 p.
RAND, T. G., AND M. Wiles. 1987. Salsuginus bermudae sp. n. (Monogenea: Ancyrocephalidae) from Fundulus bermudae Gunther and Gambusia affinis (Baird and Girard) in Bermuda. Canadian Journal of Zoology 65: 1847-1852.

SCHELL, S. C. 1985. Handbook of trematodes of North America north of Mexico. University Press of Idaho, Moscow, Idaho, $263 \mathrm{p}$. 